\title{
Diversity of Plant Parasitic Nematodes of Tree Tomato (Solanum betaceum Cav.) In Kiambu and Embu Counties, Kenya
}

\author{
Waswa Stanlous Juma ${ }^{1}$, Waceke J.W ${ }^{1}$ and Nchore S.B. ${ }^{2}$ \\ ${ }^{1}$ Department of Agriculture Science and Technology and ${ }^{2}$ Department of Plant Sciences, Kenyatta \\ University, P.O Box, 43844-00100, Nairobi, Kenya
}

Received: 17 August 2020 / Accepted 10 Sept. August 2020 / Publication date: 20 Sept. 2020

\begin{abstract}
Surveys were conducted in five areas representing different agro-ecological zones (AEZs) in Kiambu and Embu counties in Kenya during January to April 2019 cropping season to determine population density, genera diversity and distribution of plant parasitic nematodes associated with tree tomato farming systems. Nematodes were extracted from $200 \mathrm{cc}$ of soil or $5 \mathrm{~g}$ of roots using modified Baermann technique. The nematode diversity and evenness in the study areas were determined using Shannon and Simpson's indices respectively. Soil nutrients were determined using Mehlich double acid digestion. A structured questionnaire was used to get information on farming practices from sampled farmers. Meloidogyne spp. was the most dominant genera followed by Pratylenchus spp. and Helicotylenchus spp. in both soil and root samples. Githunguri recorded significantly high mean number of 15.92 and 4.29 nematodes in soil and root samples respectively. Kiambaa had the highest diversity index of 1.59 and 0.86 in soil and roots respectively while genera richness was highest in Kiambaa with 13 nematode genera in soil. Simpson's index of evenness was highest in Kiambaa with 0.69 and 0.47 in soil and root samples respectively. Githunguri had the high egg mass index of 2.00. Soil texture and elements of $\mathrm{C}, \mathrm{P}, \mathrm{K}$ and $\mathrm{N}$ together with farming practices may have contributed to the nematode community structure in the study areas.
\end{abstract}

Keywords: Agro-ecological zone, Diversity, Plant parasitic nematodes, Baermann technique

\section{Introduction}

Plant parasitic nematodes (PPNs) cause enormous crop yield losses worldwide (Karuri et al., 2017). Of all the PPNs, Meloidogyne spp. (Root-knot nematodes) is the most serious damaging nematode globally (Wangai et al., 2014; Jones et al., 2013) and it is polyphagous. In Kenya, PPNs are widely distributed in many farming systems (Karuri et al., 2017; Mwangi et al., 2014; Nzensya et al., 2014; Waceke, 2007). In Kenya, tree tomato is an important small holder fruit in most areas with an increasing market demand (Muriithi et al., 2013). Apart from home consumption, the fruits are sold and therefore provide local farmers with rural income generation, food and nutrition security and hence important in poverty alleviation (Muriithi et al., 2013). The occurrence of PPNs in tree tomato cropping systems in Kenya has not been scientifically documented previously and therefore they have not been given keen attention in terms of awareness and management.

Soil physicochemical properties play an important role in influencing the nematode community structure. Soil texture plays a critical role in nematode activities ranging from reproduction to infection. It is reported that sandy soils are favorable to PPNs Bertrand et al, 2001)

The major challenges of nematode management in tree tomato in Kenya are lack of adequate knowledge, low PPN awareness and lack of data on nematode problems. This research study was carried out to determine occurrence, diversity and distribution of PPNs ass0ciated with tree tomato growing areas in Kenya.

\section{Materials and Methods}

A nematological survey was conducted in five areas each representing different agro-ecological zones (AEZs) in Kiambu and Embu counties in Kenya to determine population density, diversity and distribution of PPNs on tree tomatoes. The study areas were: Gatundu South (1820-2280 meters above sea level) in LH1, Githunguri (1590-1850 meters a.s.1) in UM1, Embu-Runyenjes (1680-1760 meters

Corresponding Author: Waswa Stanlous Juma, Kenyatta University, P.O Box, 43844-00100, Nairobi, Kenya E-mail:waswastanlous@yahoo.com 
a.s.1) in UM2, Kiambaa (1520-1580 meters a.s.1) in UM3 and Ruiru (1360-1520 meters a.s.1) in UM4. A total of sixty farms were surveyed where ten samples were randomly taken on each farm in a zigzag fashion. The samples were composited for each farm to make one composite sample, labeled and transported in a cool box to Kenyatta University Nematology laboratory for nematode assay.

A structured questionnaire was used to get information on farming practices where the check list included farmer's name, crop variety, date of orchard establishment, altitude, farm size, crop management, previous crops and intercropping during the survey.

Nematodes were extracted from $200 \mathrm{cc}$ of soil or $5 \mathrm{~g}$ of roots using modified Baermann extraction tray method as described by Hooper et al., (2005). Roots were chopped to $1 \mathrm{~cm}$, blended in $100 \mathrm{ml}$ of water and the resultant suspension processed the same way as soil samples. Two $(2 \mathrm{ml})$ of the nematode suspension was pipetted in to a gridded counting dish and put under a microscope for counting. This was done thrice and the average recorded. Isolated nematodes were fixed, mounted on slides and identified to genus level under stereo microscope basing the identification on morphological features as described by Mai. (2018); Mekete et al. (2012); and Siddiqi (2000). Identification was based on adult female nematodes, but in some occasion second stage juveniles (J2) were also used. Another $5 \mathrm{~g}$ sub-sample of roots were washed, stained in phloxine-B $(15 \mathrm{~g} / \mathrm{L})$ and scored for egg mass index on a scale of $0-5$, where $0=$ no egg masses, $1=1-2$ egg masses, $2=3-10$ egg masses, $3=11-30$ egg masses, $4=31-100$ egg masses and $5=>100$ egg masses (Taylor \& Sasser, 1978). The egg masses were counted under a dissecting microscope.

The soil physico-chemical parameters were determined for each farm using $500 \mathrm{~g}$ of the composite soil. The soil analysis was done in Plant and Crop Laboratory in Agriculture Sciences Department at Kenyatta University. The elements of $\mathrm{P}, \mathrm{K}, \mathrm{Na}, \mathrm{Mg}, \mathrm{Ca}$ and $\mathrm{Mn}$ were analyzed using Mehlich double acid digestion method. Total organic carbon was analyzed using calorimetric method where carbon concentration was read on the spectrophotometer at $600 \mathrm{~nm}$. The total nitrogen was estimated using Kjeldahl method in which soil samples were digested using concentrated sulphuric acid containing Potassium sulphate, selenium and hydrated copper sulphate at $350^{\circ} \mathrm{C}$. Total nitrogen was then determined calorimetrically. Soil $\mathrm{pH}$ was determined using a $\mathrm{P}^{\mathrm{H}}$ meter in $1: 1(\mathrm{w} / \mathrm{v})$ suspension. Extractable phosphorus was estimated using Olsen method (for soils with $\mathrm{P}^{\mathrm{H}}=7.0$ or more). The dried soil samples were extracted in a ratio (w/v) with $0.5 \mathrm{M}$ solution of sodium bicarbonate at $\mathrm{P}^{\mathrm{H}} 8.5$. Phosphorus in the extract was determined spectrophotometrically.

The PPNs were counted and analyzed for population density while PPN diversity indices were calculated for each sample and their means computed for each of the five study areas and compared for genera diversity, richness and evenness. Calculations were based on methods of community analysis (Norton and Norton, 1978) where:

1. Population density $=$ Mean number of a given genus in $200 \mathrm{cc}$ dry soil or $5 \mathrm{~g}$ dry roots

2. Genera diversity using Shannon-Weiner index was used to calculate nematode genera diversity, to determine genera variation in the areas sampled;

Diversity $H=\sum_{i=1}^{S}$ pi logepi

$H^{\prime}=-\sum p i \ln p i$

Where: $\Sigma$ refers to "the sum of"

$\mathrm{s}=$ the number of genera in the community

$p \mathrm{i}=$ is the relative abundance (proportion) of the $\mathrm{i}^{\text {th }}$ genera in the community

$\ln =$ natural $\log$ (Shannon and Weaver, 1963).

3. Genera richness $(\mathrm{S})=$ total number of genera in a given soil sample.

4. Genera evenness was calculated using Simpson's index of diversity (Ds) to determine relative abundance with which each genus was represented in areas sampled. This was done using formula below;

$\mathrm{D}_{\mathrm{s}}=1-\sum\left(\frac{\mathrm{ni}}{\mathrm{N}}\right)^{2}$ (Simpson, 1949).

Where;

Ds $=$ Simpson's Diversity Index

$\mathrm{ni}=$ the number of individuals of genera $\mathrm{i}$

$\mathrm{N}=$ the total number of genera in the sample 
Data was organized and summarized in MS excel sheets and analysed using Analysis of Variance (ANOVA) using SAS software version 9.1 at $\mathrm{p} \leq 0.05$. Means significant were separated using Tukey's HSD at $\mathrm{p} \leq 0.05$.

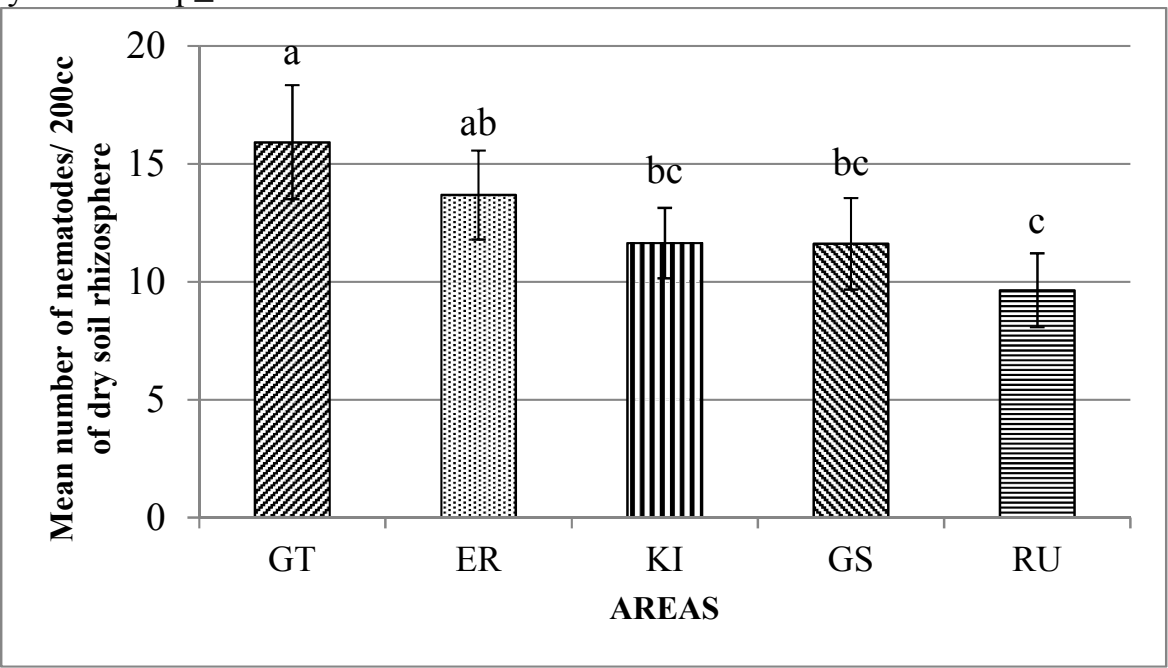

Fig. 1: Mean number of nematodes in rhizosphere soil of tree tomato in each of the study areas. Bars with the same letter(s) are not significantly different $(\mathrm{p} \geq 0.05)$ with Tukey's HSD test.

The overall mean population density of PPN genera ranged from 0.11 to 84.62 nematodes per $200 \mathrm{cc}$ of dry soil (Table 1). Meloidogyne had the highest mean population density per 200cc of dry soil followed by Helicotylenchus and Pratylenchus while Hoplolaimus was the least. Hemicycliophora, Longodorus, Trichodorus and Xiphinema also recorded high mean population though not significantly different $(\mathrm{p} \geq 0.05)$ from each other (Table 1$)$.

Table 1: Variations in population densities and overall mean of PPN genera from rhizosphere soils in the study areas

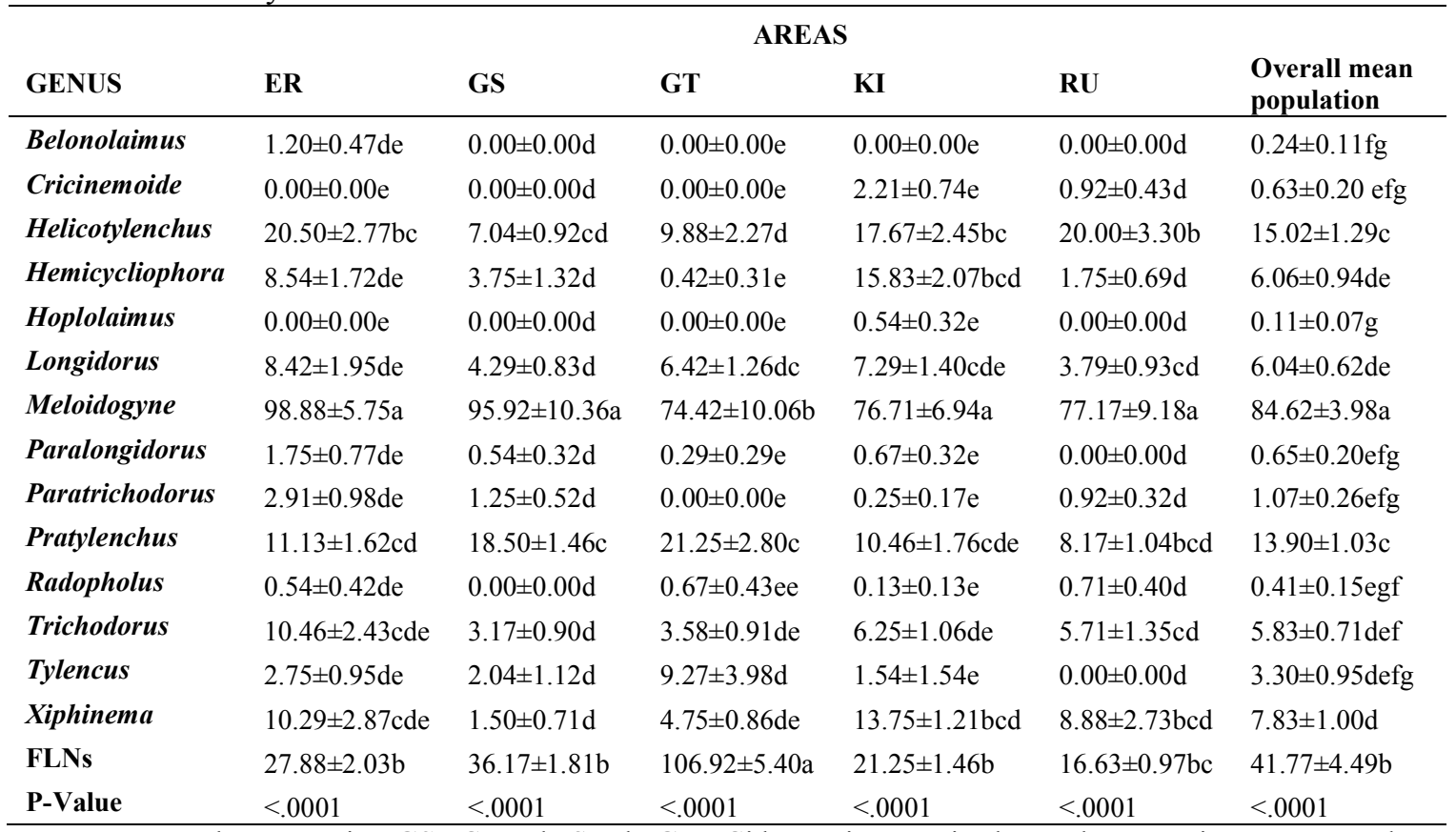

KEY: ER= Embu Runyenjes, GS= Gatundu South, GT= Githunguri, KI= Kiambaa and $\mathbf{R U}=$ Ruiru. Means are data \pm standard error (S.E) of nematodes per $200 \mathrm{cc}$ of dry soil in sixty soil samples collected in five study areas. Means with the same letter(s) in a column are not significantly different using Tukey's Honestly Significant Difference (HSD) at $\mathrm{p} \leq 0.05$. 


\section{Distribution of PPN genera in the study areas in soil rhizosphere}

There were higher significant $(\mathrm{p} \leq 0.05)$ differences in the population densities of various nematode genera in each of the study areas (Table 1). Meloidogyne spp. recorded very high population density in each area and this was significantly different from the other genera. The genera Meloidogyne, Helicotylenchus and Pratylenchus were dominant in each area apart from KI, in KI area Hemicycliophara and xiphinema genera dominated pratylenchus, while in RU area xiphinema dominated praty lenchus. ER recorded the highest mean of Meloidogyne followed by GS. Belonolaimus was present in ER only while criconemoide occurred at $\mathrm{KI}$ and RU while Hoplolaimus was present at KI only. The genera Paralongidorus and Tylenchus were found in all the areas apart from RU while Paratrichodorus was found in all areas apart from GT (Table 1).

\section{Plant parasitic nematodes and free living nematodes in tree tomato soil rhizosphere}

The number of PPNs in tree tomato rhizosphere soil samples was comparatively higher in all the study areas than free-living nematodes (FLNs). However there was significant difference $(p \leq 0.05)$ between the PPNs and FLNs in the study areas (Figure 2).

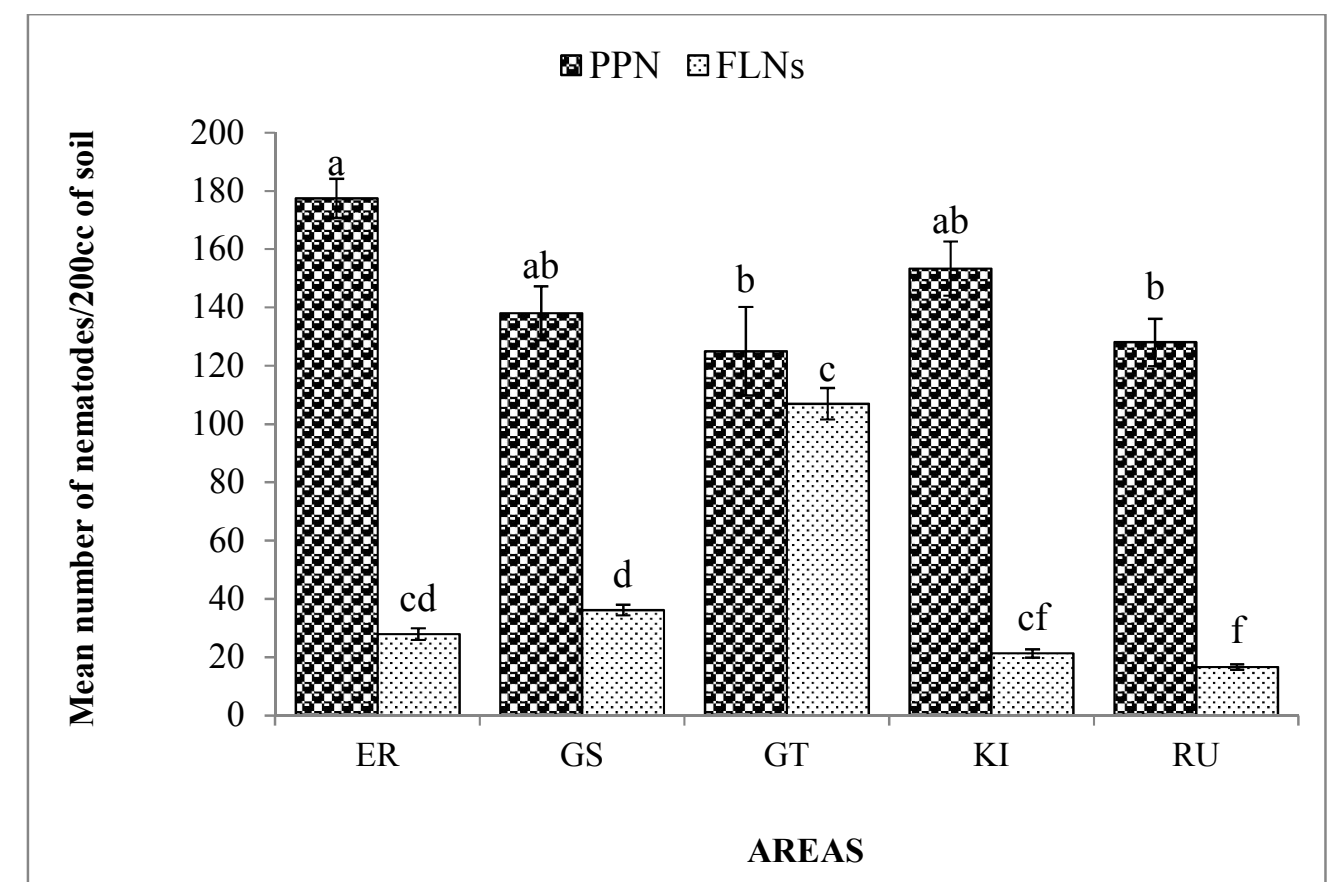

Fig. 2: Number of plant parasitic nematodes (PPNs) and free-living nematodes (FLNs) in rhizosphere soil of tree tomatoes in five study areas. Bars with the same letter(s) are not significantly different $(\mathrm{p} \geq 0.05)$ with Tukey's HSD test

\section{Population densities of PPNs from tree tomato roots}

There was a significant difference $(\mathrm{p} \leq 0.05)$ in the mean number of nematodes in the study areas. Githunguri (GT) and Embu-Runyenjes (ER) recorded the highest mean number of nematodes in roots of tree tomatoes (Figure 3). This was not significantly different $(\mathrm{p} \geq 0.05)$ from each other but significantly different with other areas. Kiambaa (KI) area recorded the lowest mean number of nematodes in roots followed by Ruiru (RU) and Gatundu South (GS) at 2.65, 3.31 and 3.30 respectively (Figure 3). 


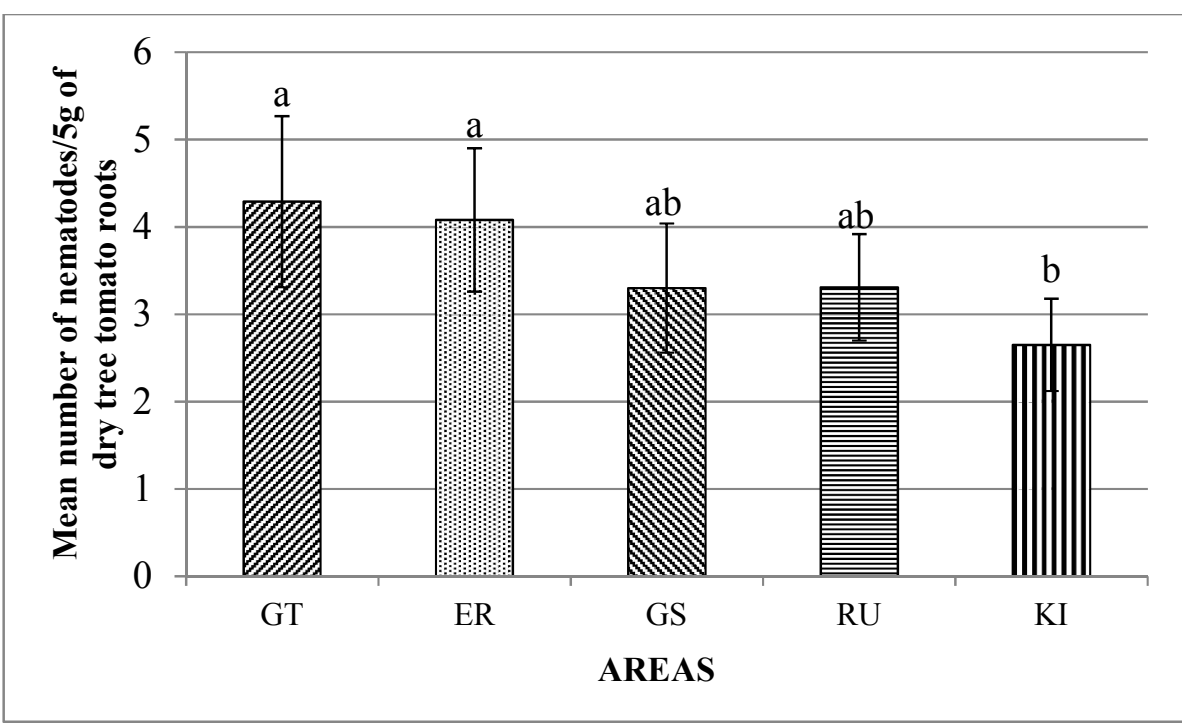

Fig. 3: Mean numbers of nematodes in roots of tree tomato in each of the study areas Bars with the same letter(s) are not significantly different ( $\mathrm{p} \geq 0.05$ ) with Tukey's HSD test

The overall mean population density of PPN genera in roots of tree tomato ranged from 0.13 nematodes for Longodorus spp. to 20.22 nematodes for Meloidogyne spp. per 5g of dry roots (Table $2)$. The root knot nematodes (Meloidogyne) recorded significantly $(\mathrm{p}<0.05)$ the highest population density than other PPN genera (Table 2). On the other hand, Helicotylenchus, Hemicycliophora and Pratylenchus had their population densities not significantly different $(\mathrm{p} \geq 0.05)$ from each other but were significantly different $(\mathrm{p} \leq 0.05)$ to other PPN genera from roots of tree tomatoes (Table 2$)$. Mean numbers of Belonolaimus, Longidorus, Trichodorus and Xiphinema though varied were not significantly different $(\mathrm{p} \geq 0.05)$ from each other and occurred in very low numbers (Table 2$)$.

\section{Distribution of PPN genera in roots of tree tomato of the study areas}

The PPN genera in roots differed significantly $(\mathrm{p} \leq 0.05)$ in in each study area. Meloidogyne was found in significantly high population density in roots in all the five study areas than any other genera. The other nematode genera were not significantly different from each other. However, there were variations with Pratylenchus and Helicotylenchus as second to Meloidogyne (Table 2).

Table 2: Variatons in population densities and overall mean of PPN genera from tree tomato roots in the study areas

\begin{tabular}{|c|c|c|c|c|c|c|}
\hline \multirow[b]{2}{*}{ GENUS } & \multicolumn{5}{|l|}{ AREAS } & \multirow[b]{2}{*}{ Overall mean population } \\
\hline & ER & GS & GT & KI & $\mathbf{R U}$ & \\
\hline Belonolaimus & $1.50 \pm 0.59 \mathrm{~b}$ & $0.00 \pm 0.00 \mathrm{~b}$ & $0.42 \pm 0.42 b$ & $0.00 \pm 0.00 \mathrm{~b}$ & $0.00 \pm 0.00 \mathrm{c}$ & $0.38 \pm \pm 0.16 \mathrm{c}$ \\
\hline Helicotylenchus & $1.63 \pm 0.64 \mathrm{~b}$ & $0.67 \pm 0.32 b$ & $2.17 \pm 0.72 \mathrm{a}$ & $1.38 \pm 0.42 b$ & $1.54 \pm 0.61 \mathrm{c}$ & $1.48 \pm 0.25^{\mathrm{bc}}$ \\
\hline Hemicycliophora & $2.21 \pm 0.45 b$ & $1.08 \pm 0.38 \mathrm{~b}$ & $0.83 \pm 0.49 \mathrm{~b}$ & $2.75 \pm 0.41 \mathrm{~b}$ & $1.42 \pm 0.47 \mathrm{c}$ & $1.66 \pm 1.66^{\mathrm{bc}}$ \\
\hline Longidorus & $0.13 \pm 0.13 b$ & $0.13 \pm 0.13 b$ & $0.29 \pm 0.29 b$ & $0.13 \pm 0.13 b$ & $0.00 \pm 0.00 \mathrm{c}$ & $0.13 \pm 0.07^{\mathrm{c}}$ \\
\hline Meloidogyne & $19.85 \pm 1.65 \mathrm{a}$ & $21.58 \pm 1.24 \mathrm{a}$ & $27.96 \pm 2.46 \mathrm{a}$ & $14.63 \pm 1.82 \mathrm{a}$ & $17.08 \pm 0.81 \mathrm{a}$ & $20.22 \pm 0.94 \mathrm{a}$ \\
\hline Pratylenchus & $3.29 \pm 1.46 \mathrm{~b}$ & $1.96 \pm 0.96 b$ & $2.25 \pm 0.88 \mathrm{~b}$ & $1.50 \pm 0.49 b$ & $6.42 \pm 1.36 \mathrm{~b}$ & $3.08 \pm 0.52^{b}$ \\
\hline Trichodorus & $3.75 \pm 3.75 b$ & $0.42 \pm 0.31 \mathrm{~b}$ & $0.29 \pm 0.29 b$ & $0.00 \pm 0.00 \mathrm{~b}$ & $0.00 \pm 0.00 \mathrm{c}$ & $0.89 \pm 0.75^{\mathrm{c}}$ \\
\hline Xiphinema & $0.25 \pm 0.17 \mathrm{~b}$ & $1.29 \pm 0.49 b$ & $0.13 \pm 0.13 b$ & $0.83 \pm 0.40 \mathrm{~b}$ & $0.00 \pm 0.00 \mathrm{c}$ & $0.50 \pm 0.14^{\mathrm{c}}$ \\
\hline P-Value & $<.0001$ & $<.0001$ & $<.0001$ & $<.0001$ & $<.0001$ & $<.0001$ \\
\hline
\end{tabular}

KEY: ER= Embu Runyenjes, GS= Gatundu South, GT $=$ Githunguri, $\mathbf{K I}=$ Kiambaa and $\mathbf{R U}=$ Ruiru. Means are data \pm standard error (S.E) of nematodes per $200 \mathrm{cc}$ of dry soil in sixty soil samples collected in five study areas. Means with the same letter(s) in a column are not significantly different. Means were separated using Tukey's Honestly Significant Difference (HSD) at $\mathrm{p} \leq 0.05$ 


\section{Plant parasitic nematode genera diversity indices in soil and roots of tree tomato}

The Shannon-Wiener diversity indices were significantly different $(\mathrm{P} \leq 0.05)$ across the five study areas in both soil and root samples. The PPNs were more diverse in the soils in Kiambaa that had a higher diversity index $>1.5$ while the PPNs less diverse in ER, GT, RU and GS in descending order that had lower diversity indices $<1.5$ (Table 3 ).

Kiambaa had higher nematode genera richness of 13 nematode genera in soil samples followed by Embu-Runyenjes (12), Gatundu South, Githunguri and Ruiru (10 each)). In root samples, EmbuRunyenjes and Githunguri had the highest number of nematode genera (8) followed by Gatundu South, Kiambaa and Ruiru respectively (Table 3).

The Simpson's evenness index in soil was significantly $(\mathrm{P} \leq 0.05)$ varied across the five areas. The Simpson's index was high in Kiambaa followed by GT, ER, RU and GS in descending order respectively for soil samples (Table 3). In root samples, Kiambaa had the highest Simpson's index of genera evenness while GS had the least (Table 3).

The egg mass indices were significantly different $(\mathrm{P} \leq 0.05)$ among the study areas. GT had the highest index followed by ER.

Table 3: PPN diversity and egg mass indices in soil and roots of tree tomato in five study areas.

\begin{tabular}{|c|c|c|c|c|c|c|c|}
\hline \multirow{3}{*}{ AREAS/AEZ } & \multicolumn{6}{|c|}{ PPN diversity indices } & \multirow{3}{*}{ EMI } \\
\hline & \multicolumn{2}{|c|}{$\begin{array}{c}\text { Genera Diversity } \\
\text { (H) }\end{array}$} & \multicolumn{2}{|c|}{ Genera Richness } & \multicolumn{2}{|c|}{$\begin{array}{c}\text { Genera } \\
\text { Evenness }\end{array}$} & \\
\hline & Soil & Roots & Soil & Roots & Soil & Roots & \\
\hline ER (UM2) & $1.47 \pm 0.07 \mathrm{ab}$ & $0.82 \pm 0.07 \mathrm{a}$ & 12 & 8 & $0.64 \pm 0.03 \mathrm{ab}$ & $0.44 \pm 0.04 \mathrm{a}$ & $1.17 \pm 0.03 \mathrm{ab}$ \\
\hline GS (LH1) & $1.09 \pm 0.08 \mathrm{c}$ & $0.56 \pm 0.09 a$ & 10 & 7 & $0.49 \pm 0.04 \mathrm{~b}$ & $0.30 \pm 0.05 \mathrm{a}$ & $0.83 \pm 0.17 \mathrm{~b}$ \\
\hline GT(UM1) & $1.37 \pm 0.08 \mathrm{abc}$ & $0.55 \pm 0.08 \mathrm{a}$ & 10 & 8 & $0.65 \pm 0.03 \mathrm{a}$ & $0.31 \pm 0.04 \mathrm{a}$ & $2.00 \pm 0.35 \mathrm{a}$ \\
\hline KI (UM3) & $1.59 \pm 0.06 \mathrm{a}$ & $0.86 \pm 0.09 a$ & 13 & 6 & $0.69 \pm 0.02 \mathrm{a}$ & $0.47 \pm 0.04 \mathrm{a}$ & $0.58 \pm 0.23 b$ \\
\hline RU(UM4) & $1.20 \pm 0.11 \mathrm{bc}$ & $0.73 \pm 0.01 \mathrm{a}$ & 10 & 4 & $0.56 \pm 0.05 \mathrm{ab}$ & $0.43 \pm 0.06 \mathrm{a}$ & $0.67 \pm 0.22 b$ \\
\hline P-Value & $<0.0006(0.0019)$ & $<0.048(0.0253)$ & & & $<0.001(0.0036)$ & $<0.03(0.0188)$ & $<0.0019(0.0088)$ \\
\hline
\end{tabular}

KEY: ER= Embu Runyenjes, GS $=$ Gatundu South, GT= Githunguri, KI $=$ Kiambaa and RU= Ruiru, EMI $=$ Eggmass index. Means are data \pm S.E. Means with the same letter(s) in a column are not significantly different with Tukey's Honestly Significant Difference (HSD) at ( $\mathrm{p} \geq 0.05)$. P-values in parenthesis are from transformed data

\section{Farming practices in tree tomato production in Kiambu and Embu counties}

The proportions of farms under tree tomato were small in all the areas. There were $75 \%$ of the farmers who grew tree tomatoes on less than 0.5 acres and only $25 \%$ used between $0.5-1$ acres of lands. None of all the sixty farmers interviewed had practiced crop rotation. However, intensive intercropping was practiced in all the study areas with $66.7 \%$ of the farmers using multiple crops 5\% with cereal crops, $1.7 \%$ with vegetable crops, $20 \%$ with cash crops and $5 \%$ with fruit crops.

There were different varieties of crops previously grown where tree tomato were planted. $36.7 \%$ had grown cash crops, 33.3\% multiple crops and 13.3\% vegetable crops (Figure 4). The purpose of growing tree tomatoes were different with $13.3 \%$ of the farmers producing for home consumption, $38 \%$ for sale and $48.3 \%$ for both.

There were $68 \%$ of farmers who did not know about nematodes while $30 \%$ reported nematode attack and $\%$ reported no nematode attack (Fig.5). 


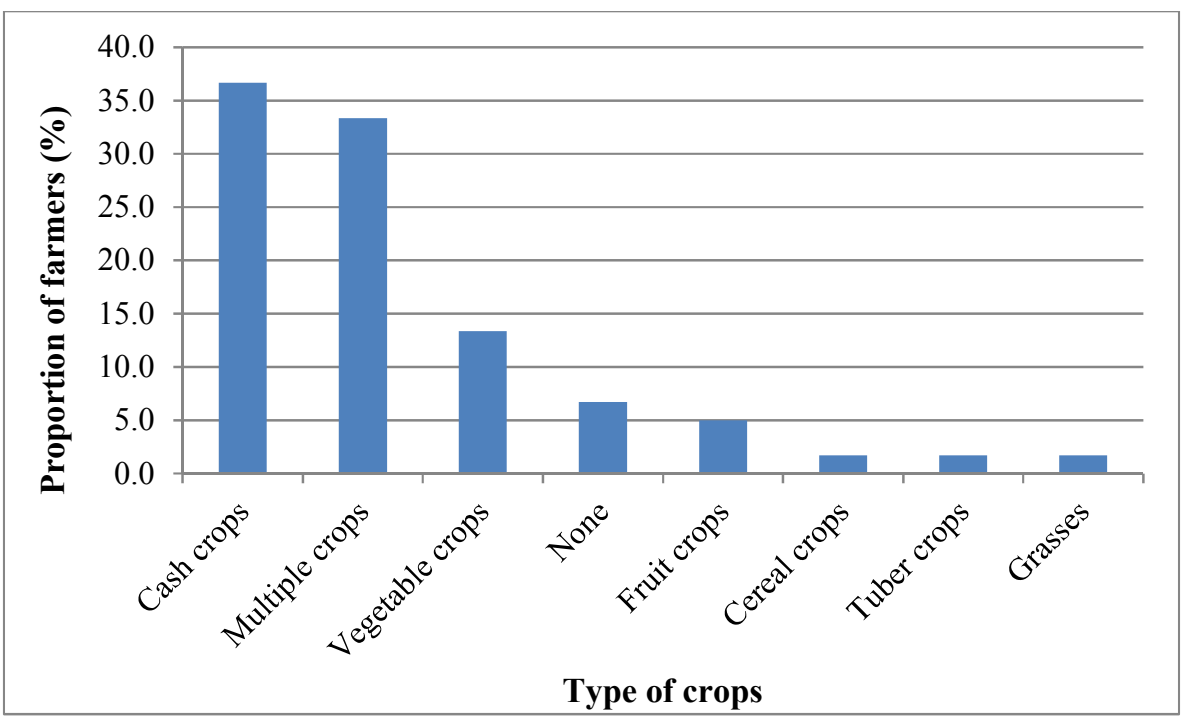

Fig. 4: previous types of crops grown before tree tomatoes by farmers in Kiambu and Embu counties

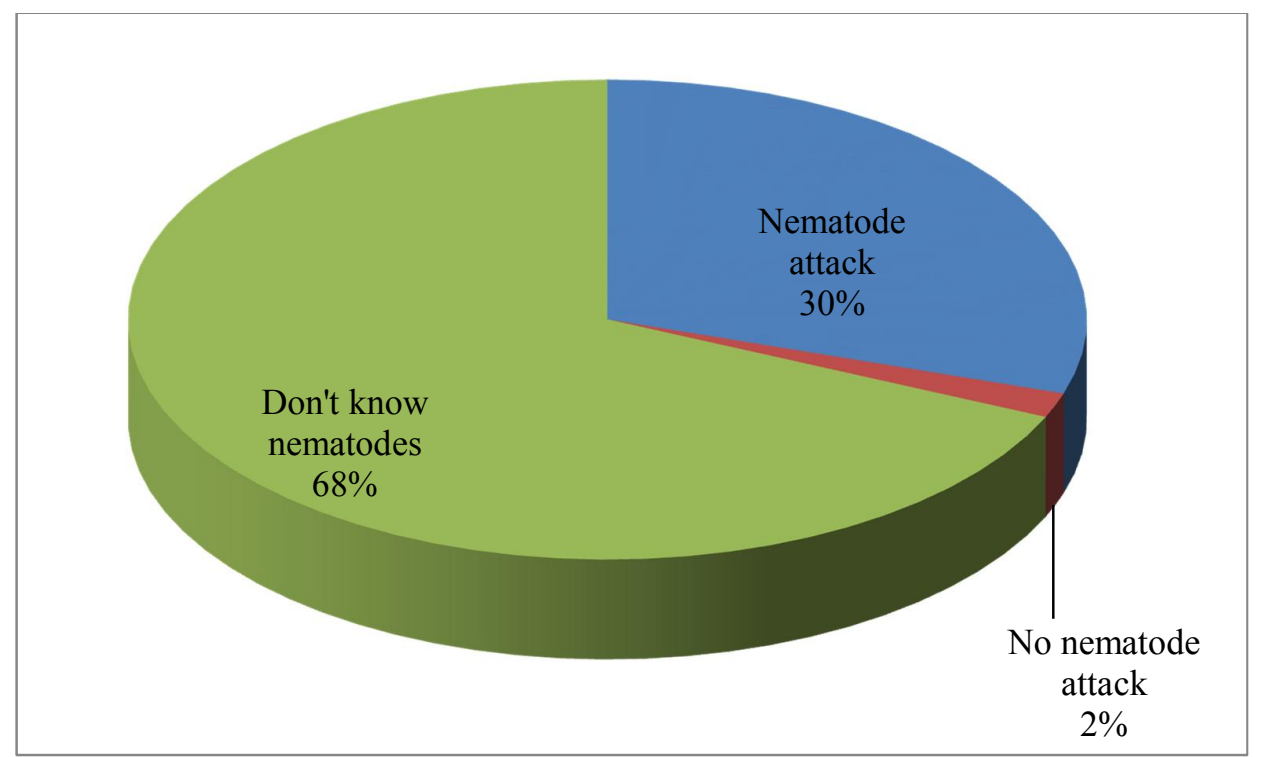

Fig. 5: Percentage of tree tomato farmers aware of nematode attack in Kiambu and Embu counties

\section{Soil physicochemical characteristics on PPN populations in the soil in Kiambu and Embu counties}

The soil physicochemical properties varied across the study areas (Table 4). The $\mathrm{pH}$ slightly varied in the study areas with ER, GS and GT recording higher $\mathrm{pH}$ values than KI and RU. The amount of Phosphorus were high in ER, GS and KI while in GT and RU were lower while, no significant differences were found in amount of potassium, $\mathrm{N}$ and $\mathrm{C}$ at all studied areasThe levels of $\mathrm{C}$ and N were lower in ER, GS and GT while in KI and RU higher. However, the soil texture did not vary much across the study areas (Table 4). The mean numbers of J2correlated with some of the soil elements. There was a significant positive correlation between J2 populations in the rhizosphere soils and phosphorus $\left(\mathrm{y}=0.2827 \mathrm{x}+149.95 ; \mathrm{R}^{2}=0.0222\right)$. In addition, J2s significantly correlated positively with potassium $(\mathrm{y}=7.1734 \mathrm{x}+150.93 ; \mathrm{R} 2=0.0039)$. 
Table 4: Mean physicochemical properties of soils from five study areas

\begin{tabular}{lllllll}
\hline \multirow{2}{*}{ Properties } & ER & GS & GT & KI & RU & P-value \\
\cline { 2 - 6 } pH & $6.20 \pm 0.4 \mathrm{ab}$ & $6.50 \pm 0.5 \mathrm{a}$ & $5.40 \pm 0.2 \mathrm{abc}$ & $5.10 \pm 0.2 \mathrm{bc}$ & $4.40 \pm 0.3 \mathrm{c}$ & 0.0006 \\
P (ppm) & $20.80 \pm 6.3 \mathrm{ab}$ & $20.00 \pm 1.3 \mathrm{ab}$ & $12.50 \pm 2.5 \mathrm{~b}$ & $39.50 \pm 9.7 \mathrm{a}$ & $12.50 \pm 1.7 \mathrm{~b}$ & 0.0111 \\
Mg (me\%) & $1.87 \pm 0.2 \mathrm{~b}$ & $1.60 \pm 0.2 \mathrm{~b}$ & $2.00 \pm 0.2 \mathrm{~b}$ & $3.70 \pm 0.4 \mathrm{a}$ & $2.00 \pm 0.1 \mathrm{~b}$ & 0.0001 \\
K (me\%) & $0.81 \pm 0.2 \mathrm{a}$ & $0.80 \pm 0.1 \mathrm{a}$ & $0.60 \pm 0.1 \mathrm{a}$ & $0.70 \pm 0.1 \mathrm{a}$ & $0.60 \pm 0.1 \mathrm{a}$ & 0.3453 \\
Na (me\%) & $0.40 \pm 0.0 \mathrm{a}$ & $0.41 \pm 0.0 \mathrm{a}$ & $0.33 \pm 0.0 \mathrm{a}$ & $0.40 \pm 0.0 \mathrm{a}$ & $0.40 \pm 0.0 \mathrm{a}$ & 0.3595 \\
Ca (me \%) & $2.00 \pm 0.1 \mathrm{~b}$ & $4.80 \pm 1.0 \mathrm{a}$ & $1.71 \pm 0.1 \mathrm{~b}$ & $1.90 \pm 0.1 \mathrm{~b}$ & $1.5 \pm 00.1 \mathrm{~b}$ & 0.0001 \\
Mn (me\%) & $1.60 \pm 0.1 \mathrm{a}$ & $1.50 \pm 0.1 \mathrm{a}$ & $1.60 \pm 0.0 \mathrm{a}$ & $1.50 \pm 0.1 \mathrm{a}$ & $1.30 \pm 0.0 \mathrm{a}$ & 0.1145 \\
Fe (ppm) & $50.50 \pm 2.7 \mathrm{a}$ & $53.30 \pm 2.5 \mathrm{a}$ & $47.10 \pm 1.4 \mathrm{a}$ & $51.90 \pm 1.6 \mathrm{a}$ & $49.61 \pm 0.4 \mathrm{a}$ & 0.2317 \\
Zn (ppm) & $18.10 \pm 0.9 \mathrm{a}$ & $21.80 \pm 1.7 \mathrm{a}$ & $19.52 \pm 0.7 \mathrm{a}$ & $18.71 \pm 0.5 \mathrm{a}$ & $18.10 \pm 0.5 \mathrm{a}$ & 0.0641 \\
Cu (ppm) & $1.41 \pm 0.2 \mathrm{ab}$ & $1.52 \pm 0.2 \mathrm{ab}$ & $1.30 \pm 0.1 \mathrm{~b}$ & $2.11 \pm 0.2 \mathrm{a}$ & $1.90 \pm 0.2 \mathrm{ab}$ & 0.0195 \\
C ( \%) & $2.50 \pm 0.3 \mathrm{a}$ & $2.61 \pm 0.2 \mathrm{a}$ & $2.42 \pm 0.4 \mathrm{a}$ & $2.80 \pm 0.1 \mathrm{a}$ & $3.67 \pm 0.6 \mathrm{a}$ & 0.2225 \\
N \%) & $0.24 \pm 0.0 \mathrm{a}$ & $0.28 \pm 0.0 \mathrm{a}$ & $0.25 \pm 0.0 \mathrm{a}$ & $0.36 \pm 0.0 \mathrm{a}$ & $0.43 \pm 0.1 \mathrm{a}$ & 0.2503 \\
Texture & SL & LS & LS & SL & SL & \\
\hline Key: ER Embur & & &
\end{tabular}

Key: ER=Embu-Runyenjes; GS=Gatundu South $\mathbf{G T}=$ Githunguri, $\mathbf{K I}=$ Kiambaa and $\mathbf{R U}=$ Ruiri. $\mathbf{S L}=$ sandy loam and $\mathbf{L S}=$ loamy. Means are data \pm S.E. Means followed by the same letter (s) in each row are not significantly different according to Tukey's HSD test at $\mathrm{P} \geq 0.05$.

\section{Discussion}

Githunguri and Embu-Runyenjes recorded higher PPN populations. The high PPN population density in these two areas could be linked to intercropping tree tomatoes with susceptible crops like beans, kales, spinach, maize and cabbages observed during the survey. This may explain the high numbers of nematodes in the soil. Also the previous crops grown on the farms where tree tomatoes were established may explain the occurrence of high numbers of nematodes in roots. The previous susceptible crops provided the initial inoculum for tree tomato infection after planting. Prolonged mono-cropping of susceptible host plants may lead to plant parasitic nematodes build ups which causes serious crop damage (Bhan, et al., 2010). These areas also receives substantial amount of rainfall that ensures prolonged moisture in the soil for nematode movement. Although GS receives good amount of rainfall (Jaetzold and Schmidt, 1983), it had low PPN population density compared to GT and ER. This could be due to farmers applying inorganic fertilizers and fresh un-decomposed cattle manure noticed during the survey. Upon decomposition, organic manure releases toxic chemicals against PPNs and enhances proliferation of antagonistic micro-organisms against PPNS. KI and RU receive depressed rainfall and therefore relatively dry ( Jaetzold and Schmidt, 1983). It is reported that areas with hot and dry seasons have reduced PPNs (Hussey, 1996). This may have been the cause of low numbers of PPNs from these areas.

This study revealed that the PPN genera were spread across the tree tomato growing areas with Meloidogyne spp. being the most dominant genera isolated followed by Pratylenchus and Helicotylechus in all the study areas. In Ecuador and Colombia, Meloidogyne spp., Pratylenchus spp. and Helicotylechus spp. were also recorded as dominant genera in the same crop (Vaquez and Soria 2017; Ramirez et al., 2015). These PPNs are polyphagous and their high numbers is linked to intercropping of tree tomatoes with susceptible host crops. It was also noted during the survey that many farmers had previously grown susceptible crops on the farms where tree tomato were established. This could be the reason for high numbers of PPNs isolated from soil and roots. Hoplolaimus, Belonolaimus, Croconemoides, Paralongidorus, Radopholus, Longidorus, Xiphinema and Trichodorus recorded very low population densities. This could be due to the presence of other aggressive dominant genera and interspecific competition from other PPNs (Blake 1969). Belonolaimus spp., Criconemoide spp., Hoplolaimus spp., Paratichodorus spp., and Tylenchus spp. are parasites of many vegetable crops like cabbage, capsicum, tomatoes and cow peas (Anwar et al., 2007). Farmers intercropping many vegetable crops with tree tomatoes explain their presence in some of the areas. Also the low numbers of these PPNs may indicate their ability to co-exist as external or internal parasites. However, the presence of Radopholus could be attributed to intercropping with 
banana plantations in some of the study areas together with warm temperature in the study area that supports thriving of the nematode.

The number of free-living nematodes (FLNs) was low compared to PPNs. The low numbers of FLNs in cultivated farms is an indicator of loss of soil fertility and also due to soil degradations. The FLNs are highly sensitive to soil disturbances. This could have been the case in most of the study areas since many farmers were growing tree tomatoes on less than 0.5 acres of land. These small parcels of land are prone to soil disturbances due to intercropping and continuous cropping making the numbers of FLNs to go down. In this case, PPN numbers go up and became a big menace (Hillocks and Waller, 1997). In Githunguri, the number of FLNs was almost equal with the PPNs. Some of the tree tomato farmers were using cattle manure in the soil which could have increased the population of FLNs in the soil. Use of OAs has been reported to improve soil health, increase yields and enhances biodiversity of soil flora and fauna (Kimpinski et al., 2003).

Nematode genera diversity was generally low in both roots and soil samples. This could be attributed to the small parcels of land used by farmers and intensive intercropping.. This could have been the case in most of the study areas. Agricultural intensification is linked to soil disturbances through tillage, organic amendments applications, use of pesticides and inorganic fertilizers and planting narrow range of plant genotypes or complete monoculture. This leads to a decline in nematode abundance, richness and diversity due to emergence of a single species and change genera composition (Kimenju et al., 2009; Yeates and Bongers, 1999; Yeates, 1999). Low Shannon diversity numbers are linked to intercropping of tea and coffee monocultures. High application of agrochemicals like pesticides in coffee and fertilizers used in tea could be the factors (Kimenju et al., 2009). Agro-ecosystems with reduced tillage have high nematode diversity while agrochemical use and practice of monoculture causes loss of nematode biodiversity (Kimenju et al., 2009). The Genera richness in the roots was however low as compared to soil and this could be due to host specificity and preference of PPNs. On the other hand, the intensive intercropping in the study areas could be the reason why nematode genera richness was high in the soil samples. Tree tomatoes were highly intercropped with multiple crops like many vegetable varieties, cash crops like tea and coffee, cereal crops like maize and fruit crops all of which are also favorable hosts to various nematode genera. The high EMI in GT and ER may be due to high numbers of Meloidogyne spp. in both soil and roots.

It was evident from the study that tree tomato is a suitable host to various PPNs in tree tomato growing areas. Plant parasitic nematodes have been reported in many parts of the world (Ramírez-Gil et al., 2017; Ramirez et al., 2015) and in Kenya (Mwangi et al., 2014; Waceke 2007; Waiganjo et al., 2006). The distribution of PPNs in different areas may have also been influenced by soil physicochemical parameters and farming practices. Kandji et al. (2001) and Kimenju et al. (2009) showed that soil physic-chemical properties influence the occurrence, abundance, distribution and community structure of nematode. The low numbers of PPNs in Ruiru may be linked to high levels of carbon and nitrogen in that area in comparison, Githunguri and Embu -Runyenjes which recorded high numbers of nematodes in roots had low levels of carbon and nitrogen. Organic carbon is known to increase the number of antagonistic micro-organisms in the soil which reduces the numbers of PPNs. It has been reported that animal manure has been used in the management of RKNs and other PPNs (Nchore et al., 2012). Soil organic amendments (OAs) enhances the build-up of nematode trapping fungi than inorganic fertilizers (Agbenin 2004). A study conducted by Nchore (2012) on indigenous leafy vegetables indicate that mono-cropping with susceptible hosts leads to increased Meloidogyne infection. High levels of potassium are known to increase PPNs in the soil. Badra \& Yousif (1979) notes that Potassium enhances rapid development of nematodes by reducing their life cycle. High Phosphorus and Potassium levels increase nematode populations because of its essential role in nematode multiplication, nutrition and production of eggs. Potassium also improves root growth which increases the root surface area for nematode attack and feeding (Badra and Yousif, 1979). This explains the high numbers of PPNs in Embu-Runyenjes and Kiambaa which had high potassium. However, Ruiru had low levels of Potassium revealing the occurrence of low numbers of PPNs. This observation was in agreement with studies by Kandji et al. (2001) and Badra and Yousif (1979).

Most soils in the study areas were sandy loam (SL) and loam sand (LS). These types of soil structure supports high nematode population densities (Talwana et al., 2008). This might have led to the high numbers of PPNs in the study areas. These types of soil is highly porous with good aeration 
and this favors movement of nematodes (Talwana et al.,2008; McLean and Lawrence 2000; Norton and Norton, 1978). Most of the study areas receive substantial amount of rainfall around the year with good agricultural potential (Jaetzold et al., 2006) and this creates perfect conditions for nematodes to flourish. Moisture increases nematode populations (Wallace 1983). The $\mathrm{pH}$ was within range tolerated by most PPNs. Most ago-ecosystems fall in the range of $\mathrm{pH} 4-8$ (Nyasani et al., 2008) and therefore tree tomato growing areas are suitable habitats for nematode survival. However, other findings report that extremes of $\mathrm{pH}$ affect nematode survival (Nyasani et al., 2008).

\section{Conclusion}

This study revealed that tree tomato is attacked by diverse PPNs in Kenya. The most dominant genera limiting tree tomato production were Meloidogyne, Pratylenchus and Helicotylenchus. Soil physicochemical properties and farming practices are the major factors contributing to the diversity of PPNs in tree tomato growing areas. Thus, there is need for further research on responses of different tree tomato varieties to root-knot nematodes ( $\mathrm{RKN})$ and create farmers awareness to PPN problems.

\section{References}

Agbenin, O.N., 2004. Potentials of organic amendments in the control of plant parasitic nematodes. Plant Protection Science, 40(1): 21-25.

Anwar, S. A., A. Zia, M. Hussain, and M. Kamran, 2007. Host suitability of selected plants to Meloidogyne incognita in the Punjab, Pakistan. International Journal of Nematology, 17(2): 144.

Badra, T. and G. M. Yousif, 1979. Comparative effects of potassium levels on growth and mineral composition of intact and nematized cowpea and sour orange seedlings. Nematologia Mediterranea, 7(1).

Bertrand, B., F. Anthony, and P. Lashermes, 2001. Breeding for resistance to Meloidogyne exigua in Coffea arabica by introgression of resistance genes of Coffea canephora. Plant Pathology, 50(5): 637-643.

Bhan, M., R. McSorley, and C. A. Chase, 2010. Effect of cropping system complexity on plantparasitic nematodes associated with organically grown vegetables in Florida. Nematropica, 40(1): 53-70.

Blake, C. 1969. Nematodes of banana and their control. In. Nematodes of Tropical Crops. Technical Communication by Commonwealth Bureau of Helminthology, 40, 109-132.

Hillocks, R. J. and J. M. Waller, 1997. Associations between soilborne pathogens and other soilinhabiting microorganisms. In: Hillocks, R.J. and Waller, J.M. (Eds), Soil Disease of Tropical Crops (Pp. 351-364). Wallingford, UK: CAB International.

Hooper, D. J., J. Hallmann, and S. A. Subbotin, 2005. 3 Methods for Extraction, Processing and and detection of and soil nematodes. In: Luc, M., Sikora, R, A. and Bridge (Eds.). Plant Parasitic Nematodes in Subtropical and Tropical Agriculture, $2^{\text {nd }}$ Edition (Pp, 53-86). Wallingford, UK: CAB International.

Hussey, R.S., 1996. Nematode pathogenesis and resistance in plants. Plant cell 8: 755-741.

Jaetzold, R., H. Schmidt, B. Hornetz, and C. Shisanya, 2006. Farm management handbook of Kenya Vol. II-Natural Conditions and Farm Management Information-2nd Edition part c; East Kenya Subpart C1 Eastern Province. Ministry of Agriculture, Nairobi, Kenya.

Jaetzold, R. and H. Schmidt, 1983. Farm Management Handbook of Kenya (Vol. II, Part C): Natural Conditions and Farm Management Information, East Kenya.

Jones, J.T., A. Haegeman, E.G.J. Danchin, H.S. Gaur, J. Helder, M.G.K. Jones, T. Kikuchi, R. Manzanilla-López, J.E. Palomares-Rius, W.I.M.M.L.Wesemael and R.N. Perry , 2013. Top 10 plant-parasitic nematodes in molecular plant pathology. Molecular Plant Pathology 14:946-961.

Kandji, S. T., C. K. Ogol, and A. Albrecht, 2001. Diversity of plant-parasitic nematodes and their relationships with some soil physico-chemical characteristics in improved fallows in western Kenya. Applied Soil Ecology, 18(2):143-157.

Karuri, W. H., D. Olago, R. Neilson, E. Njeri, A. Opere, and P. Ndegwa, 2017. Plant parasitic nematode assemblages associated with sweet potato in Kenya and their relationship with environmental variables. Tropical plant pathology. 42:1-2. 
Kimenju, J. W., N.K. Karanja, G.K. Mutua, B.M. Rimberia, and P.M. Wachira, 2009. Nematode community structure as influenced by land use and intensity of cultivation. Tropical and Subtropical Agroecosystems, 11(2): 353-360.

Kimpinski, J., C.E. Gallant, R. Henry, J.A., Macleod, J.B. Sanderson, and A.V. Sturz, 2003. Effect of compost and manure soil amendments on nematodes and on yields of potato and barley: A 7-year study. Journal of Nematology, 35(3): 289.

Mai, W., 2018. Plant-parasitic nematodes: A pictorial key to genera. Cornell University Press.

McLean, K.S. and G.W. Lawrence, 2000. A survey of plant-parasitic nematodes associated with cotton in northeastern Louisiana. Journal of Nematology, 32(4S):508.

Mekete, T., A.A. Dababat, N. Sekora, F. Akyazi, and E. Abebe, 2012. Identification key for agriculturally important plant-parasitic nematodes: A manual for nematology. CIMMYT.

Muriithi, C., F. Matiri, F. Kihanda, D. Maina, and F. Kasungo, 2013. Evaluation of potential of tree tomato production and marketing in Eastern Kenya for improved nutrition and food security. Joint Proceedings of the 27th Soil Science Society of East Africa and the 6th African Soil Science Society Conference.

Mwangi, J.M., J.W.Waceke, and G.M. Kariuki, 2014. Occurrence and abundance of plant parasitic nematodes in cabbage-based cropping systems in Kenya. Journal of Agriculture and Biological Sciences, 9:326-332.

Nchore, S.B., 2012. Incidence, prevalence and management of root-knot nematodes (Meloidogyne spp.) on selected indigenous leafy vegetables in kisii and trans-mara counties, Kenya, M.sc thesis, Kenyatta University, Nairobi, Kenya.

Norton, D.C. and D.C. Norton, 1978. Ecology of plant-parasitic nematodes. Wiley New York

Nyasani, J.O., J.W. Kimenju, F.M. Olubayo, S.I. Shibairo and G.K. Mutua, 2008. Occurrence of Entomopathogenic Nematodes and their Potential in the Management of Diamondback Moth in Kale. Asian Journal of Plant Sciences. 7(3): 314-318.

Ramirez, F., R. Grijalra, X. Navarrete, and R. Guerrero, 2015. Phytoparasitic nematodes associated with tree tomato (Solanum betaceum Cav.) in the provinces of Imbura, Pichincha and Tungurahua,Ecuador. Interoceanic Km 14 1/2. The MAGAP Farm, Tumbaco, Ecuador

Ramírez-Gil, J.G., A. Gil-Aguirre, and J.G. Morales-Osorio, 2017. Etiología de enfermedades del cultivo de tomate de árbol (Solanum betaceum CAV.). Revista de Protección Vegetal, 32(1): 33 51.

Shannon, C.E. and W. Weaver, 1963. The Mathematical Theory of Communication,(first published in 1949). Urbana: University of Illinois Press.

Siddiqi, M. R., 2000. Tylenchida: Parasites of plants and insects ( $2^{\text {nd }}$ edition). Wallingford, UK. CAB International

Simpson, E. H., 1949. Measurement of diversity. Nature, 163(4148): 688-688.

Talwana, H.L., M.M. Butseya, and G. Tusime, 2008. Occurence of plant parasitic nematodes and factors that enhance population build-up in cereal-based cropping systems in Uganda. African Crop Science Journal, 16(2).

Taylor, A.L. and J.N. Sasser, 1978. Biology, identification and control of root-knot nematodes (Meloidogyne Species). North Carolina State University Graphics.

Vásquez, P.U. and C.A. Soria, 2017. Nematodos parásitos asociados con tomate de árbol (Solanum betaceum Cav.) en la sierra del Ecuador. Revista Ecuatoriana de Medicina y Ciencias Biológicas, 38(2): 107-118.

Waceke, J.W., 2007. Plant parasitic nematodes associated with cabbages in Kenya. In: African Crop Science Conference Proceedings (8:1071-1074).

Waiganjo, M.M., N.M. Wabule, D. Nyongesa, J.M. Kibaki, I. Onyango, S. B. Wepukhulu, and N.M. Muthoka, 2006. Tomato production in Kirinyaga district, Kenya, a baseline survey report. Kenya Agricultural Research Institute, Nairobi, Kenya, 1-43.

Wallace, H.R., 1983. Interactions between nematodes and other factors on plants. Journal of Nematology, 15(2): 221.

Wangai, K.J., M.J. Nzesya, M.W. Maina, W.M. Peter, and G.K. Elijah, 2014. Plant parasitic nematodes associated with coffee in Kenya and factors influencing their occurrence, abundance and diversity. Journal of Biology, Agriculture and Health care. 4:120-129 
Yeates, G.W., 1999. Effects of plants on nematode community structure. Annual Review of Phytopathology, 37(1): 127-149.

Yeates, G.W. and T. Bongers, 1999. Nematode diversity in agroecosystems. In Invertebrate Biodiversity as Bioindicators of Sustainable Landscapes, 113-135. 